\title{
Pengaruh Penggantian Agregat Halus dengan Serbuk Ban Bekas pada Campuran Beton Terhadap Daya Redam Getaran
}

\author{
Muhammad Farhan Mufid Kusuma*, Restu Faizah', Guntur Nugrohob \\ ${ }^{a}$ Mahasiswa Program Pasca Sarjana, Departemen Teknik Sipil dan Lingkungan, Universitas Gadjah Mada, Yogyakarta \\ ${ }^{b}$ Program Studi Teknik Sipil, Fakultas Teknik, Universitas Muhammadiyah Yogyakarta
}

Riwayat Artikel

Diserahkan

1 Desember 2020

Direvisi

4 Januari 2021

Diterima

1 Februari 2021

\begin{abstract}
Abstrak
Limbah ban bekas merupakan salah satu limbah yang sulit untuk diatasi, karena karet ban sulit untuk di urai bahkan didaur ulang. Limbah ini, akan semakin meningkat seriring dengan bertambahnya produksi kendaraan di masyarakat. Salah satu upaya untuk mengolah limbah ban bekas adalah merubah ban bekas menjadi serbuk yang dapat dimanfaatkan untuk peredam gesekan di lapangan, merubah ban bekas menjadi minyak, bahkan merubahnya menjadi furniture. Inovasi dalam bidang teknik sipil ialah dengan mengganti agregat halus dengan ban bekas. Penggantian ini diharapkan dapat menciptakan beton ramah lingkungan. Metode yang digunakan adalah membuat benda uji berbentuk silinder dan balok, serta melakukan varian serbuk ban bekas dengan presentase $0 \%, 5 \%, 10 \%, 15 \%, 20 \%$. Benda uji silinder digunakan untuk mengetahui kuat tekan yang dimiliki tiap varian presentase serbuk ban bekas, sedangkan benda uji balok digunakan untuk mengetahui daya redam pada masing-masing varian campuran. Pengujian kuat tekan beton dilakukan menggunakan mesin compression tester machine, dan pengujian daya redam beton menggunakan akselerometer getaran. Hasil dari pengujian dapat diketahui bahwa, semakin banyak presentase serbuk ban bekas yang digunakan makan akan semakin menurun kuat tekan yang dimiliki beton. Sedangkan, untuk daya redam yang dimiliki, semakin banyak presentase campuran serbuk ban bekas maka semakin besar pula daya redam yang dimiliki. Hasil tersebut dapat menjadi sebuah tolak ukur untuk pengembangan beton ramah lingkungan, dan dapat menahan getaran lebih baik.
\end{abstract}

Kata-kata kunci: serbuk ban bekas, akselerometer, getaran, kuat tekan, daya redam

\section{PENDAHULUAN}

Permasalahan limbah merupakan masalah yang sedang dihadapi tidak hanya Indonesia, namun juga dunia. Limbah plastik, kertas, dan sebagainya merupakan bentuk pencemaran lingkungan yang sangat mengganggu ekosistem alam sekitar. Salah satu limbah yang ditemui adalah limbah ban bekas. Limbah ini termasuk dalam limbah yang sulit untuk di daur ulang, atau dimanfaatkan kembali. Umumnya, ban yang sudah tidak dipakai maka akan ditinggalkan begitu saja, bahkan sedikit sekali perhatian pemerintah terhadap limbah ini. Inovasi dalam bidang teknik sipil untuk limbah ini adalah penggunaan serbuk ban bekas pada campuran beton. Penggunaan serutan ban bekas ini sudah banyak dilakukan pengujian, salah satunya adalah penggunaan biji karet sebagai pengganti agregat kasar (Yuhesti, 2019). Beton yang diberi campuran karet akan mengalami penurunan kuat tekan. Penelitian sebelumnya mengenai kuat tekan beton dengan campuran karet pernah dilakukan oleh Yung dkk (2013).
Hasil penelitiannya diketahui bahwa terjadi penurunan pada setiap banyaknya campuran yang di campurkan. Putra (2015) pada campuran beton dan limbah ban sebagai agregatnya, memiliki kuat lentur yang lebih kecil dibandingkan dengan beton normal. Sedangkan untuk redaman, pernah dilakukan penelitian sebelumnya oleh Liang dkk (2016), Lee dkk (2018), dan Faizah (2019), dalam penelitiannya mengungkapkan semakin banyak campuran serutan karet ban pada beton maka semakin meningkat daya redam yang dimiliki beton.

Penelitian ini bertujuan untuk menentukan daya redam yang dimiliki suatu beton dengan penggantian agregat halus dengan serbuk ban bekas. Kemudian, menguji kuat tekan yang dimiliki sebagai acuan layak atau tidak penggunaan serbuk ban bekas pada campuran beton untuk bidang struktur bangunan, dan sebagai inovasi beton remah lingkungan. 


\section{METODE PENELITIAN}

\subsection{Desain Campuran Beton}

Desain campuran beton menggunakan cara menurut peraturan SNI 7656-2012 (BSN, 2012). Kuat tekan beton yang direncanakan adalah $35 \mathrm{MPa}$. Pada Tabel 1 menyajikan desain campuran beton per $\mathrm{m}^{3}$ pada tiap varian.

Tabel 1 Desain campuiuran beton untuk setiap $1 \mathrm{~m}^{3}$

\begin{tabular}{llllll}
\hline Kadar & \multicolumn{4}{c}{ Bahan $(\mathrm{kg} / \mathrm{m} 3)$} \\
\cline { 2 - 5 } Serbuk & Semen & Air & Kerikil & Pasir & Serbuk \\
\hline $0 \%$ & 578,2 & 148,11 & 1083,85 & 873,69 & - \\
$5 \%$ & & & & 830,19 & 43,69 \\
$10 \%$ & & & & 786,5 & 87,39 \\
$15 \%$ & & & & 742,8 & 131,08 \\
$20 \%$ & & & & 1083,85 & 174,78 \\
\hline
\end{tabular}

\subsection{Uji Slump Flow}

Pengujian slump beton segar dilakukan pada tiap-tiap variasi campuran beton menggunakan kerucut abrams.

\subsection{Uji Kuat Tekan}

Pengujian kuat tekan dilakukan pada umur 28 hari dengan menggunakan alat uji tekan compression tester machine. Beban maksimum $\left(\mathrm{P}_{\max }\right)$ yang menyebabkan keruntuhan benda uji dicatat. Kuat tekan beton dihitung menggunakan persamaan 1 .

$f_{c}^{\prime}=\frac{P_{\max }}{A}$

dengan,

$\mathrm{f}_{\mathrm{c}}{ }^{\prime} \quad=$ kuat tekan maksimum (MPa)

$\mathrm{P}_{\max } \quad=$ beban maksimum $(\mathrm{N})$

A $\quad=$ luas penampang $\left(\mathrm{mm}^{2}\right)$

\subsection{Pengujian Daya Redam}

Pengujian daya redam menggunakan alat akselerometer untuk mendeteksi getaran di dalam beton. Persiapan pengujian daya redam dapat dilihat pada Gambar 1(a) yang merupakan alat akselerometer yang dihubungkan dengan program matlab sebagai pembacanya. Pada Gambar 1(b) menunjukkan pemasangan sensor pada beton, dan pada Gambar 1(c) merupakan cara pemberian pukulan pada beton, yang akan dilihat daya redam yang dimiliki beton tersebut. Gelombang getaran direkam melalui perangkat MATLAB dan data logger sebagai penyimpan dan pembaca sensor. Beton yang diuji masing-masing berumur 28 hari. Perhitungan daya redam menggunakan persamaan (2) dan (3).

$$
\begin{aligned}
& \delta=h \frac{y_{1}}{y_{2}} \\
& \varepsilon=\frac{\delta}{\sum N}
\end{aligned}
$$

dengan,

$$
\begin{array}{ll}
\delta & =\text { logarithmic decrement } \\
\mathrm{y}_{1}, \mathrm{y}_{2} & =\text { simpangan getaran }(\mathrm{cm}) \\
\varepsilon & =\text { koefisien redaman }(\%)
\end{array}
$$

Gelombang getaran yang ditunjukan pada Gambar 2, merupakan tipikal peristiwa redaman dalam beton, $\mathrm{y}_{1}$ merupakan titik awal/puncak suatu gelombang setelah diberi pukulan, dan $\mathrm{y}_{2}$ merupakan nilai setengah dari y1 yang merupakan penurunan gelombang.

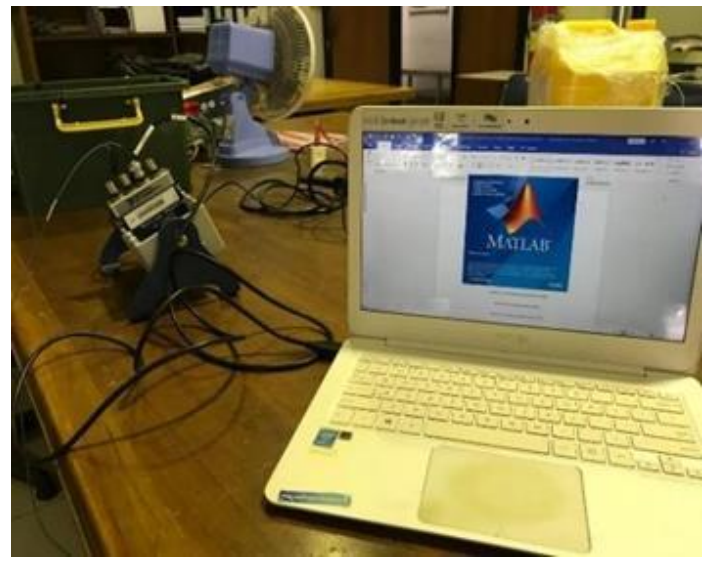

(a)

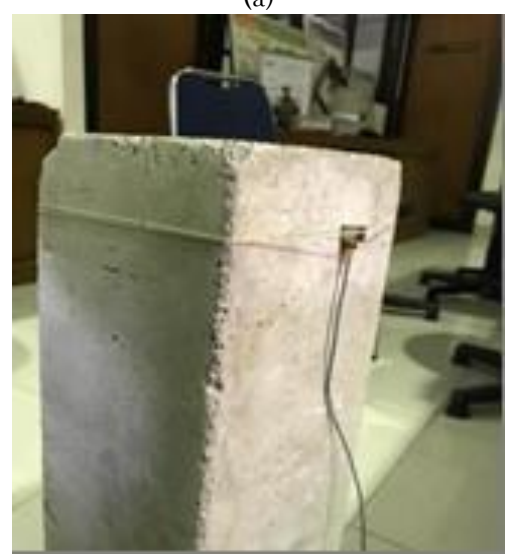

(b)

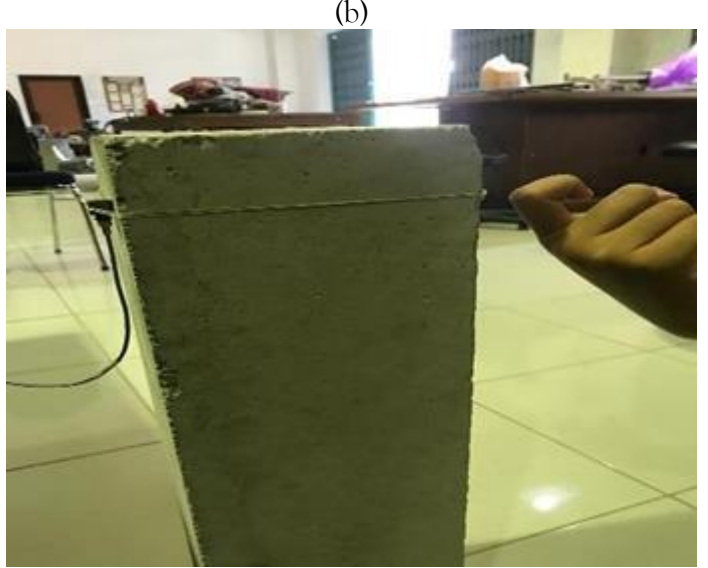

Gambar 2(a) akselerometer dan program matlab; (b) pemasangan sensor ke benda uji; (c) pemberian pukulan

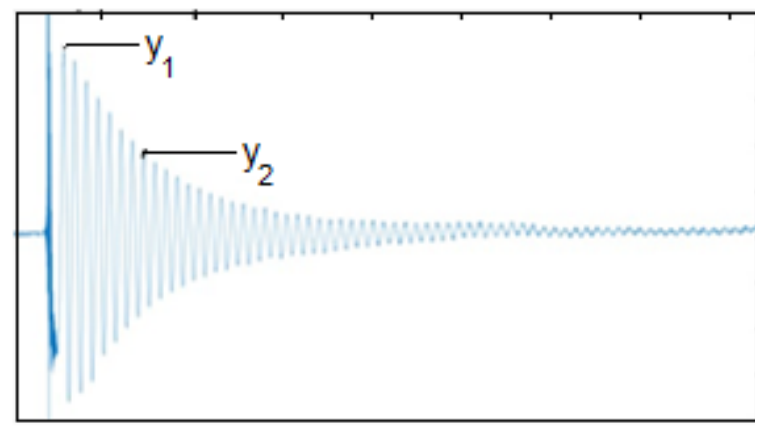

Gambar 1 Tipikal gelombang getaran 


\section{HASIL DAN PEMBAHASAN}

3.1 Pengaruh campuran serbuk baan bekas terhadap nilai slump flow

Pengujian dilakukan untuk mengetahui tingkat workability pada suatu campuran beton. Hasil pengujian slump campuran beton dan serbuk ban bekas dapat dilihat pada Gambar 3. Nilai slump yang dihasilkan mengalami kenaikan nilai slump yang mengartikan bahwa campuran sangat encer, karena ikatan antar partikel agregat tidak menyatu dengan baik, akibat serbuk ban bekas yang tidak bisa berikatan maupun menyerap air.

Secara umum dapat diketahui bahwa semakin banyak campuran serbuk ban bekas maka semakin tinggi nilai slump yang dimiliki. Campuran serbuk ban bekas menyebabkan material agregat sulit untuk tercampur sehingga campuran beton cepat mengering akibat air yang tidak dapat tercampur sempurna. Hal ini menyebabkan ketidak padatan beton dan mengurangi kuat tekan yang dimiliki.

\subsection{Pengaruh variasi campuran serbuk ban bekas terhadap kuat tekan}

Hasil pengujian kuat tekan beton dengan variasi presentase campuran mengalami penurunan seiring banyaknya campuran serbuk ban bekas pada beton. Hal ini disebabkan karena material yang tidak berikatan dengan baik akibat serbuk ban bekas di dalam beton. Gambar 4 menunjukan penurunan yang signifikan berada pada campuran serbuk $5 \%$ yang memiliki nilai kuat tekan $20,5 \mathrm{MPa}$. Sedangkan pada variasi $10 \%$; 15\%, dan $20 \%$ memiliki nilai kuat tekan berturut-turut $15,8 \mathrm{MPa}, 12,9$ $\mathrm{MPa}$, dan 12,3 MPa. Hasil pengujian kuat tekan beton dapat diketahui bahwa, penggantian serbuk ban bekas pada campuran beton menurunkan kuat tekan yang dimiliki beton. Semakin banyak campuran sebuk ban bekas pada beton maka semakin menurunkan kaut tekan yang dimiliki. Menurunnya kuat tekan ini diakibatkan kepadatan campuran beton yang berkurang karena serbuk ban bekas.

\subsection{Pengaruh variasi campuran serbuk ban bekas terhadap daya redam}

Hasil pengujian dapat dilihat pada Tabel 2. Semakin banyak campuran serbuk ban bekas maka semakin tinggi daya redam yang dimiliki beton. Gambar 5 menunjukkan grafik hasil dari nilai daya redam yang miliki beton dengan variasi yang berbeda. Secara garis besar, terjadi peningkatan pada pengujian yang dilakukan. Nilai daya redam pada beton Normal, 5\%; 10\%; 15\%; dan 20\% berturut-turut sebesar $1,42 \% ; 2,1 \% ; 2,13 \% ; 2,3 \%$; dan $2,6 \%$. Hasil dari pengujian daya redam dapat diketahui bahwa, pennggantian serbuk ban bekas terhadap agregat halus pada campuran beton meningkatkan daya redam getaran yang dimiliki beton. Semakin tinggi presentase campuran serbuk ban bekas pada beton, maka semakin tinggi pula daya redam yang dimiliki beton. Hal ini disebabkan getaran yang terjadi pada beton, dihambat oleh sebuk ban bekas yang terdapat pada beton, sehingga getaran tidak menyebabkan kerussakan atau keretakan pada beton. Serbuk ban bekas menyebabkan pengikatan antar material dan air tidak sempuran dan kepdatan yang dimiliki pun rendah.

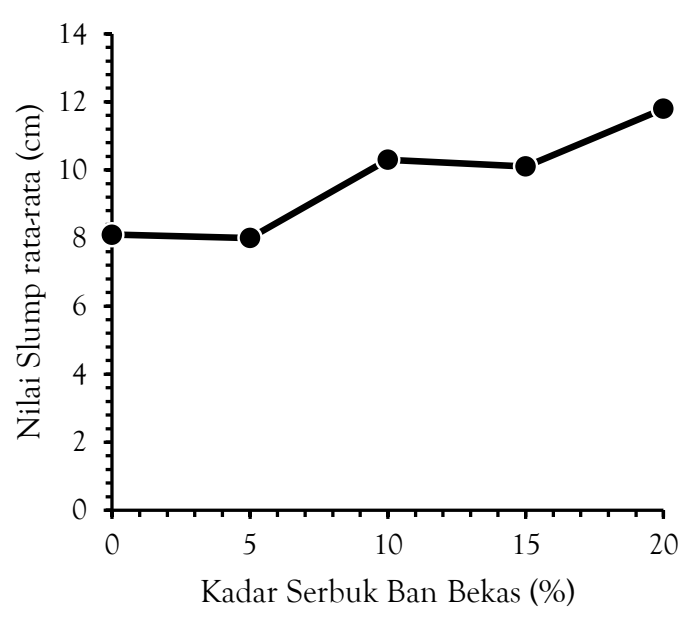

Gambar 3 Grafik hubungan presentase serbuk ban bekas dan nilai slump

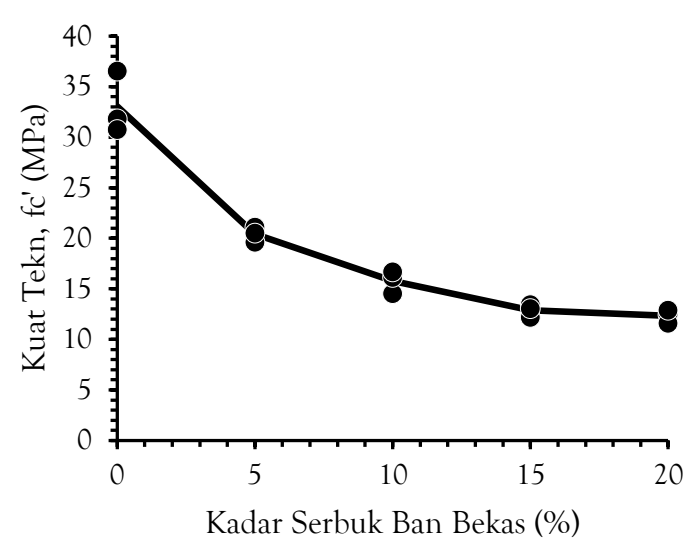

- Data Rerata

Gambar 4 Grafik hubungan presentase serbuk ban bekas dan nilai kuat tekan beton

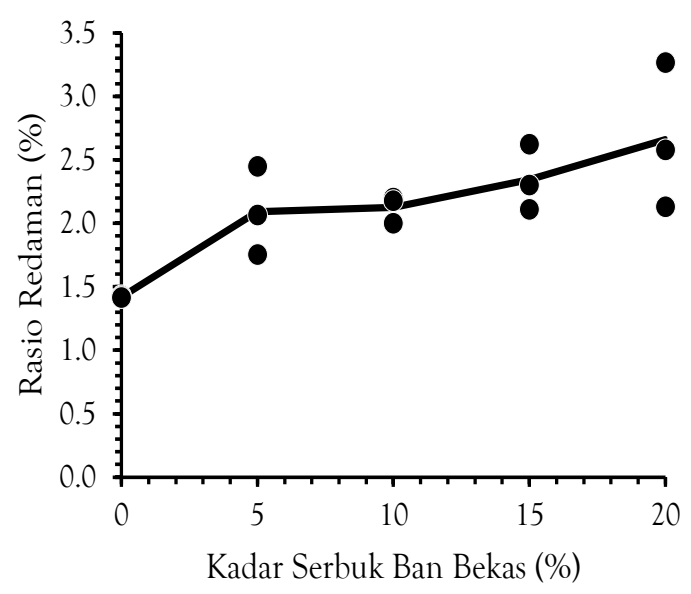

- Data $\longrightarrow$ Rerata

Gambar 5 Hubungan persentase serbuk ban bekas dan rasio redaman 
Tabel 2 Hasil pengujian redaman

\begin{tabular}{|c|c|c|c|c|c|c|c|c|}
\hline No & Variasi & $\mathrm{y}_{1}$ & $\mathrm{y}_{2}$ & $\mathrm{~N}$ & $\begin{array}{l}\text { Logarithmic } \\
\text { Decrement }(\delta)\end{array}$ & $\begin{array}{l}\text { Damping Rasio } \\
(\varepsilon)\end{array}$ & $(\%)$ & $\begin{array}{l}\text { Rata-rata } \\
(\%)\end{array}$ \\
\hline 1 & Normal & 0,281 & 0,137 & 8 & 0,717 & 0,0143 & 1,43 & \multirow{3}{*}{1,42} \\
\hline 2 & Normal & 0,212 & 0,102 & 7 & 0,625 & 0,0142 & 1,42 & \\
\hline 3 & Normal & 0,063 & 0,031 & 8 & 0,711 & 0,0141 & 1,41 & \\
\hline 4 & Serbuk 5\% & 0,043 & 0,020 & 6 & 0,778 & 0,020 & 2,06 & \multirow{3}{*}{2,09} \\
\hline 5 & Serbuk 5\% & 0,073 & 0,034 & 5 & 0,769 & 0,024 & 2,44 & \\
\hline 6 & Serbuk 5\% & 0,041 & 0,021 & 6 & 0,661 & 0,017 & 1,75 & \\
\hline 7 & Serbuk 10\% & 0,033 & 0,016 & 5 & 0,690 & 0,021 & 2,19 & \multirow{3}{*}{2,12} \\
\hline 8 & Serbuk $10 \%$ & 0,045 & 0,021 & 6 & 0,754 & 0,020 & 2,00 & \\
\hline 9 & Serbuk $10 \%$ & 0,050 & 0,025 & 5 & 0,684 & 0,021 & 2,17 & \\
\hline 10 & Serbuk $15 \%$ & 0,110 & 0,049 & 6 & 0,795 & 0,021 & 2,11 & \multirow{3}{*}{2,34} \\
\hline 11 & Serbuk $15 \%$ & 0,103 & 0,050 & 5 & 0,723 & 0,023 & 2,30 & \\
\hline 12 & Serbuk $15 \%$ & 0,067 & 0,035 & 4 & 0,659 & 0,026 & 2,62 & \\
\hline 13 & Serbuk 20\% & 0,048 & 0,021 & 5 & 0,810 & 0,025 & 2,57 & \multirow{3}{*}{2,64} \\
\hline 14 & Serbuk 20\% & 0,037 & 0,016 & 4 & 0,821 & 0,032 & 3,26 & \\
\hline 15 & Serbuk $20 \%$ & 0,039 & 0,017 & 6 & 0,792 & 0,021 & 2,10 & \\
\hline
\end{tabular}

\section{KESIMPULAN}

Berdasarkan hasil pengujian yang telah dilakukan dan diuraikan pada bab-bab sebelumnya dapat ditarik kesimpulan sebagai berikut :

1. Penggunaan serbuk ban bekas sebagai pengganti agregat halus menyebabkan campuran beton mengalami penurunan pada tingkat workability, sehingga pencetakan beton sulit dilakukan seiring banyaknya presentase varian serbuk ban bekas.

2. Penggantian serbuk ban bekas meningkatkan kemampuan daya redam yang dimiliki beton terhadap getara yang diterima, sehingga beton tidak mengalami kerusakan atau keretakan.

3. Seiring betambahnya campuran serbuk ban bekas pada beton, menurunkan kuat tekan yang dimiliki beton.

\section{Daftar Pustaka}

BSN, 2012, SNI 7656-2012: Tata cara pemilihan campuran untuk beton normal, beton berat dan beton massa, Badan Standardisasi Nasional, Jakarta
Faizah, R., Henricus, P., Akhmad, A., 2019, An Investigation on Mechanical Properties and Damping Behaviour of Hardened Mortar with Rubber Tire Crumbs (RTC), MATEC Web Conferences 258, 05002.

Lee, K. S., Jeong-Il, C.., Se, E. P., Jae-Seung, H., dan Bang, Y. L., 2018, Damping Property Of Prepacked Concrete Incorporating Coarse Aggregates Coated With Polyurethane, Cement and Concrete Composites 93, 301308.

Liang, C., Tiejun L., Jianzhuang, X., Dujian, Z., Qiuwei, Y., 2016, The Damping Property Of Recycled Aggregate Concrete. Construction and Building Materials 102, 834842.

Putra, L. O., 2015, Perilaku Lentur Beton Yang Menggunakan Limbah Ban Sebagai Agregat, Tugas Akhir. Universitas Hasanudin, Makassar.

Yuhesti, S., 2014, Kajian Eksperimental Penggunaan Limbah Biji Karet Sebagai Pengganti Agregat Kasar Pada Campuran Beton Ringan Kombinasi Pasir Tanjung Raja dan Conplast WP421, Jurnal Teknik Sipil dan Lingkungan 2(3), 434-444

Yung, H. W., Lin ,C. Y., Lee, H. H., 2013, A Study Of The Durability Properties Of Waste Tire Rubber Applied To SelfCompacting Concrete, Construction and Building Materials 4, 665-672. 